\title{
Lower Gastrointestinal Surgery: Robotic Surgery versus Laparoscopic Procedures
}

\author{
Julia-Kristin Baukloha ${ }^{a}$ Daniel Perez ${ }^{a}$ \\ Matthias Reeh ${ }^{a}$ \\ Matthias Biebl ${ }^{\mathrm{b}}$ \\ Johann Pratschke ${ }^{\mathrm{b}}$ Felix Aigner ${ }^{\mathrm{b}}$ \\ ${ }^{a}$ Department of General, Visceral and Thoracic Surgery, University Hospital Hamburg-Eppendorf, Hamburg, Germany; \\ ${ }^{b}$ Department of Surgery, Charité - Universitätsmedizin Berlin, Campus Mitte and Virchow Klinikum, Berlin, Germany
}

Jakob R. Izbickia

Keywords

Colorectal cancer - Rectal cancer .

Minimally invasive surgery - Laparoscopic surgery .

Robotic surgery

\section{Summary}

Introduction: For a long time, the comprehensive application of minimally invasive techniques in lower gastrointestinal (Gl) surgery was substantially impaired by inherent anatomical and technical complexities. Recently, several new techniques such as robotic operating platforms and transanal total mesorectal excision (taTME) have revolutionized the minimally invasive approach. This review aims to depict the current state of the art and evaluates the advantages and drawbacks in regard to perioperative outcome and quality of oncological resection. Methods: A systematic literature search was performed using the search terms 'colorectal cancer', 'rectal cancer', 'minimally invasive surgery', 'laparoscopic surgery', and 'robotic' to identify relevant studies reporting on robotic surgery (RS) either alone or in comparison to laparoscopic surgery (LS). Publications on taTME were analyzed separately. Results: 69 studies reporting on RS with a total of 20,872 patients, and 17 articles on taTME including 881 patients, were identified. Conclusion: Both RS and taTME can facilitate a minimally invasive approach for lower GI surgery in an increasing number of patients. Furthermore, combining both techniques might become an auspicious approach in selected patients; further prospective and randomized trials are needed to verify its benefits over conventional laTME.

(C) 2018 S. Karger GmbH, Freiburg

\section{Introduction}

In recent years, several innovative techniques have fundamentally changed the landscape of visceral surgery. The laparoscopic approach, which found widespread acceptance after 1987 following the evolution of video technology [1], became a crucial milestone and formed the basis for the development of various minimally invasive surgical techniques. Conventional open procedures were gradually superseded by laparoscopic surgery (LS). Pivotal benefits of LS include decreased postoperative pain, improved cosmetic results, reduced length of hospital stay (LOS), faster recovery back to normal diet and bowel function, along with comparable oncological outcome [2-7].

In lower gastrointestinal surgery, the broad implementation of minimally invasive procedures has been substantially hampered by the demanding anatomical and technical complexities of colorectal surgery such as the narrow male pelvis, obesity, locally advanced disease, low rectal masses, or the necessity of intracorporeal ileocolic anastomosis [8, 9]. Moreover, certain pitfalls of the laparoscopic approach, such as 2-dimensional vision, tremor, and limitations in triangulation and motility, potentially impede the procedure. Resulting in overall conversion rates of up to $30 \%[2,5,10-14]$, which is associated with poor oncological outcome and higher morbidity $[2,15]$, these drawbacks crucially impair surgical outcome $[8,9,16]$. Bridging this gap, several advancements now serve to facilitate minimally invasive surgery in challenging surgical situations.

The most profound change has resulted from the development of robotic operating platforms. First described in 2001 [17], the robotic approach has found increasing acceptance in colorectal surgery. Its implementation has been driven by several advantages of robotics: In particular, a stable camera platform with 3-dimensional imaging and tremor filtering, instruments with multiple degrees of freedom, motion scaling, ambidextrous capability, a third arm for fixed retraction, better ergonomics, and less fatigue [1821]. Nevertheless, downsides of robotic surgery (RS) need to be borne in mind, such as high costs, bulky cart, longer operating time, and lack of haptic sense [22]. Colorectal LS and RS have been

\section{KARGER}

(c) 2018 S. Karger GmbH, Freiburg

Fax +497614520714
PD Dr. med. Daniel R. Perez 


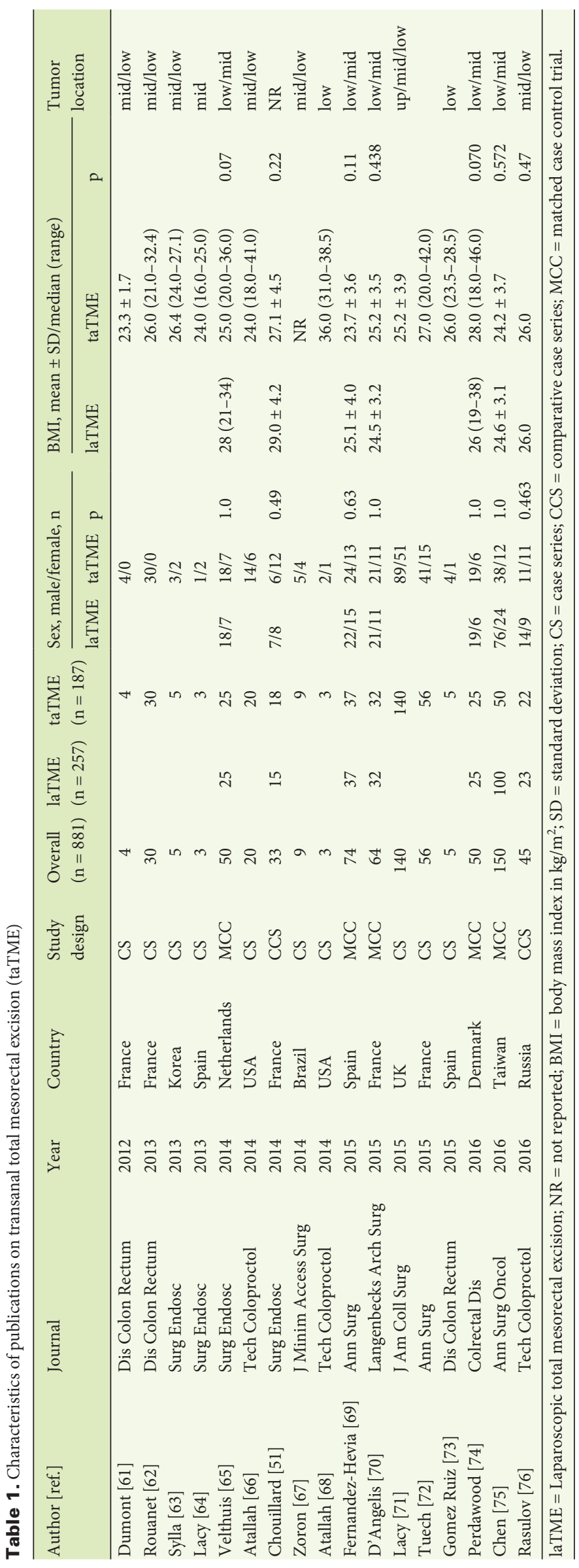

shown to provide equal perioperative and oncological outcome even in patients presenting with complicated anatomical situations such as narrow male pelvis or obesity [22-28].

This review aims to provide an up-to-date literature review on studies reporting on minimally invasive techniques for colorectal malignancies. 69 publications on RS and LS as well as 17 studies on transanal total mesorectal excision (taTME) and laparoscopic TME (laTME) were evaluated. In particular, this review assesses perioperative outcome and oncological quality of resection.

\section{Methods}

A systematic literature search (PubMed, Science Direct, and Google Scholar) was conducted according to the PRISMA guidelines [29] using the search terms 'colorectal cancer', 'rectal cancer', 'minimally invasive surgery', 'laparoscopic surgery', and 'robotic'. Publications on case series of RS either alone or in comparison to LS were eligible. The resulting reference list was complemented with additional hand-searched studies missed by this search strategy. Studies including non-malignant cases were excluded. Due to the large number of eligible robotic TME (roTME) publications, we considered only comparative case series published after 2010 with a minimum of 100 patients for closer analysis. A complete listing of all articles is provided in supplementary tables 1-4 (available at http://www.karger.com/ProdukteDB/produkte.asp?doi=486008). Publications on taTME were treated separately; articles on taTME case series were eligible as well. Duplicates were excluded in a first screening. After this, eligibility was proven based on the title, and the abstracts of all remaining articles were revised according to inclusion and exclusion criteria. Finally, full-text checks ensured that the articles met the inclusion criteria. Characteristics of the publications are depicted in supplementary table 1 (available at $h t t p: / / w w w . k a r g e r . c o m / P r o d u k t-$ eDB/produkte.asp?doi=486008) and table 1 .

\section{Robotic-Assisted Colorectal Surgery}

\section{Operative Time}

One drawback of RS for colorectal cancer is the increased operative time leading to longer anesthesia, as shown by significant results of 25 publications (supplementary table 2; available at $h t t p: / /$ www.karger.com/ProdukteDB/produkte.asp?doi=486008). Compared to only 9 studies with comparable operative time, this clearly illustrates the current situation of RS.

In our experience, especially for roTME, the initial period including the learning curve is quite laborious. However, operating times comparable to laTME are achieved after 20-30 cases. It is noteworthy that the majority of current publications represent or at least include the learning curve of the respective surgical study group.

Another important aspect are multiquadrant operations: In cases of required simultaneous splenic flexure mobilization and rectal resection, robotic platforms are of limited use. To avoid a time-consuming second docking and additional trocars, some surgeons prefer to use a hybrid technique and perform splenic flexure mobilization laparoscopically.

\section{Hospital Stay and Readmission}

LOS was comparatively investigated by 32 studies; the majority found equal time to discharge following RS and LS (supplementary 
table 2; available at http://www.karger.com/ProdukteDB/produkte. asp?doi=486008), although 8 publications revealed a significantly shorter LOS for RS. Out of 24 studies with equal results for LOS, statistical significance was barely missed in 2 series with a $\mathrm{p}$ value of 0.05 , potentially due to an underpowered analysis.

Readmission was reported in 7 series; 6 presented equal results for RS and LS, whereas the most comprehensive multicenter matched case control study (MCC) revealed a significant difference with a slightly higher readmission rate for RS (9.1 vs. 9.4\%; $\mathrm{p}=0.049$ ).

\section{Morbidity}

While LS in comparison with a conventional open approach convinces with reduced intraoperative complications and perioperative morbidity, shorter immobilization, less pain, and faster recovery $[4,6,11,30]$, it is questionable whether RS is capable of further improving perioperative convalescence.

This is endorsed by studies included in this review (supplementary table 3; available at http://www.karger.com/ProdukteDB/ produkte.asp?doi=486008): Major and minor complication rates reveal equal perioperative morbidity for LS and RS. Merely 1 publication shows significantly less major complications for RS [31]. Several publications presented a reduced need of analgesics and shorter time to liquid or soft diet, others revealed equivalent results for postoperative diet.

In summary, while LS already reduces postoperative major morbidity to a low level of $0-20 \%$, RS is capable of providing equal postoperative morbidity.

\section{Conversion Rate}

Several complexities of colorectal surgery can limit the technical feasibility of conventional LS leading to conversion rates of up to $5-30 \%$ [32]. However, conversion to an open approach, while providing technical feasibility, is also associated with increased morbidity, higher rates of metachronous metastasis and local recurrence, as well as poor disease-free survival, in-hospital mortality, and transfusion requirements [2, 33-37].

Out of 69 evaluated publications, 32 reported comparatively on conversion rates (supplementary table 3; available at $h t t p: / / w w w$. karger.com/ProdukteDB/produkte.asp?doi=486008). 4 studies showed significantly lower conversion rates for RS, and 28 revealed non-significant results: 7 publications showed higher conversion rates for RS, whereas 16 reported on lower and 5 on equivalent rates. 1 huge MCC trial demonstrated significantly higher conversion rates for RS. In all cases, several aspects of study design seem to affect the results. On the one hand, despite huge differences in conversion rates (e.g., LS vs. RS, 11.1:0\%; 20:5\%; 10.5:5.2\%), plenty of studies did not reach statistical significance. The vast majority of included publications are retrospective analyses and represent the surgical learning curve. As the evidence grade is currently low for RS, further publications are needed to clarify whether this is the result of underpowered analysis. Furthermore, upcoming studies with exclusion of initial cases might potentially reveal different conversion rates. Overall, the current literature demonstrates equal to lower conversion rates for RS.

\section{Nerve-Sparing Procedure}

Improved functional outcome has been reported following RS due to nerve-sparing surgical techniques. Significantly more voiding dysfunction following LS compared to RS was found by Cho et al. [38]. Furthermore, this study reported on equal rates of sexual dysfunction, whereas RS, in a prospective case series by Kim et al. [39], was associated with faster recovery of bladder voiding and sexual function.

\section{Quality of Mesorectal Excision}

Several pathological details serve as surrogate parameter for locoregional tumor clearance. Among them, completeness of TME is a main parameter for quality of oncological resection [40]. Especially in circumferential resection margin(CRM)-negative patients, substantial damage to the mesorectal specimen is a main risk factor for local recurrence [41]. Poor quality of mesorectal resection has been shown to be associated with low rectal tumors $[40,42]$.

Comparable results for the quality of TME with RS and LS are reported by 12 out of 14 comparative publications. Baik et al. [22] demonstrated significantly higher TME quality following LS in a randomized trial of $18 \mathrm{RS}$ patients, whereas Allemann et al. [43] showed higher TME quality for RS (95 vs. 55\%; $\mathrm{p}=0.0003$ ).

\section{Oncological Outcome and Efficiency}

Besides TME quality, a positive CRM provides high predictive value for local recurrence and worse disease-specific survival [40, $44,45]$. Similar to poor TME quality, a significant association of positive CRM with low tumors has been demonstrated [40, 42].

RS provided an equal proportion of positive CRM in 23 studies. D'Annibale et al. [46] showed a significantly smaller proportion of positive CRM for RS compared to LS (LS vs. RS, 12 vs. $0 \%$; $\mathrm{p}=0.022$ ).

A total of 33 publications reported comparatively on harvested lymph nodes. 26 studies found equal results, whereas 4 studies showed significantly more retrieved lymph nodes for RS and 3 studies found more lymph nodes following LS (supplementary table 4; available at http://www.karger.com/ProdukteDB/produkte. asp?doi=486008).

As already mentioned, data with higher evidence on RS in colorectal malignancies is scarce. 2 randomized trials and 10 MCC studies are included in this analysis.

Cho et al. [38], in an MCC, revealed for RS and LS not only no differences in oncological surrogate parameters such as CRM or TME quality but also equal results for disease-specific survival, overall survival, and 5-year disease-free survival.

In 2018, the publication of the first randomized controlled trial (RCT) comparing robotic and laparoscopic rectal resection is expected. The ROLARR trial is a superiority trial observing resection margins, 3-year local recurrence, and disease-specific survival [47]. First presentations at international conferences (ASCO 2016 and ACS 2016) revealed similar surgical quality and safety. Additionally, a subgroup analysis showed lower conversion rates in demanding cases such as obese male patients with bulky and low tumors. 
Table 2. Operation time, hospital stay, and readmission in publications on transanal total mesorectal excision (taTME)

\begin{tabular}{|c|c|c|c|c|c|c|c|c|c|c|c|}
\hline \multirow[t]{2}{*}{ Author [ref.] } & \multirow[t]{2}{*}{ Year } & \multirow{2}{*}{$\begin{array}{l}\text { Study } \\
\text { design }\end{array}$} & \multicolumn{3}{|l|}{ Operation time } & \multicolumn{3}{|c|}{ Hospital stay } & \multicolumn{3}{|c|}{ Readmission } \\
\hline & & & laTME, min & taTME, min & $\mathrm{p}$ & $\begin{array}{l}\text { laTME, } \\
\text { days }\end{array}$ & $\begin{array}{l}\text { taTME, } \\
\text { days }\end{array}$ & $\mathrm{p}$ & $\begin{array}{l}\text { laTME, } \\
\%\end{array}$ & $\begin{array}{l}\text { taTME, } \\
\%\end{array}$ & $\mathrm{p}$ \\
\hline Dumont [61] & 2012 & CS & & $360(270-460)$ & & & $13(3-8)$ & & & NR & \\
\hline Rouanet [62] & 2013 & CS & & $304(120-432)$ & & & $14(9-25)$ & & & NR & \\
\hline Sylla [63] & 2013 & CS & & $274.6 \pm 85.4$ & & & $5.2 \pm 2.6$ & & & 20 & \\
\hline Lacy [64] & 2013 & CS & & 143 & & & $5(4-5)$ & & & 33.3 & \\
\hline Velthuis [65] & 2014 & MCC & NR & NR & & NR & NR & & NR & NR & \\
\hline Atallah [66] & 2014 & CS & & $243(140-495)$ & & & $4.5(3-24)$ & & & NR & \\
\hline Chouillard [51] & 2014 & CCS & $275 \pm 58$ & $245 \pm 66$ & 0.18 & $9.4(6-19)$ & $10.4(4-29)$ & $>0.05$ & NR & NR & \\
\hline Zoron [67] & 2014 & CS & & 311 & & & 7.56 & & & NR & \\
\hline Atallah [68] & 2014 & CS & & $380(339-409)$ & & & $4(4-5)$ & & & 66.6 & \\
\hline Fernandez-Hevia [69] & 2015 & MCC & $252 \pm 50$ & $215 \pm 60$ & $<0.01$ & $6.8 \pm 3$ & $9 \pm 7.6$ & 0.1 & 22 & 6 & 0.03 \\
\hline D’Angelis [70] & 2015 & MCC & $225 \pm 51.7$ & $195 \pm 43.6$ & 0.017 & $9.8 \pm 4$ & $7.8 \pm 2.1$ & 0.018 & 9.4 & 6.2 & 1.0 \\
\hline Lacy $[71]$ & 2015 & CS & & $166 \pm 57$ & & & $6(5-9)$ & & & NR & \\
\hline Tuech [72] & 2015 & CS & & $270(150-495)$ & & & $10(6-21)$ & & & NR & \\
\hline Gomez Ruiz [73] & 2015 & CS & & $370(256-445)$ & & & $6(5-7)$ & & & NR & \\
\hline Perdawood [74] & 2016 & MCC & $351(220-480)$ & $300(235-420)$ & 0.002 & $14(4-50)$ & $5(2-43)$ & 0.020 & 16 & 16 & 1.0 \\
\hline Chen [75] & 2016 & MCC & $178.7 \pm 34.8$ & $182.1 \pm 55.4$ & 0.632 & $7.1 \pm 3.8$ & $7.4 \pm 2.5$ & 0.425 & 110 & 6 & 0.415 \\
\hline Rasulov [76] & 2016 & CCS & $305(210-455)$ & $320(265-495)$ & 0.624 & $8(4-17)$ & $8(6-18)$ & 0.606 & NR & NR & \\
\hline
\end{tabular}

laTME = Laparoscopic total mesorectal excision; $\mathrm{NR}=$ not reported; $\mathrm{CS}=$ case series; $\mathrm{CCS}=$ comparative case series; $\mathrm{MCC}=$ matched case control trial.

\section{Transanal TME}

The technique of taTME was retrospectively compared to open surgery and conventional LS in various trials proposing taTME to be safe and feasible $[48,49]$. Furthermore, studies suggest that taTME has certain advantages in low rectal resection compared to LS or open surgery such as lower conversion rates, especially in obese patients, and better preservation of autonomic function, while oncological results are similar [50]. So far, little data exists on comparative or matched-pair analyses regarding laTME and taTME, not to mention roTME. Table 1 demonstrates patient characteristics with most studies including cancers in both the mid and the low rectal third; however, none of them preformed subgroup analyses, which would have been interesting especially with regard to location-dependent differences in oncological outcome (e.g., COLOR II trial) [32].

Operation time in the taTME group was significantly shorter in 3 studies where 2-team approaches for taTME were feasible, with significantly shorter LOS in 2 of the studies and a significantly lower readmission rate in 1 study (table 2). Minor and major complications rates as far as reported were similar in the laTME and the taTME group with conversion rates from $0 \%$ in most studies to $44 \%$ in 1 small series of 33 patients undergoing taTME [51] (table 3). Regarding pathological surrogate parameters, completeness of TME (complete or nearly complete) was achieved in $>90 \%$ of the taTME specimens in most of the studies with one showing a significant difference compared to laTME (table 4). No significant difference was observed with regard to CRM and number of harvested lymph nodes.

In a comparative study of our own data, robotic low anterior resection (RLAR) and taTME for rectal cancer were equal with regard to oncological surrogate parameters, suggesting that both pro- cedures are equally applicable for resection of low rectal cancer especially in patients with anatomical limitations such as male gender and bulky tumors (unpublished data). No differences were found between intraoperative complication and conversion rates.

\section{Conclusion}

The multicenter randomized trials COLOR II and COREAN showed equal disease-free survival and local recurrence for laTME and conventional open resection [3, 32]. Conversely, non-inferiority could not be demonstrated for laTME in comparison to open surgery in the latest published multicenter randomized trials ALaCaRT and ACOSOG-Z6051 [52, 53]. However, ALaCaRT and ACOSOG-Z6051 based their analysis on pathological surrogate parameters for oncological outcome only, such as negative distal and circumferential margins and quality of TME, whereas follow-up parameters are not provided $[52,53]$.

A comparison to COLOR II, which revealed a significantly higher percentage of CRM-positive resections in the subgroup of lower rectal cancer following open resection [30] and showed equivalent disease-free survival and local recurrence in a 3-year follow-up [32], sheds a different light on these findings.

The CLASICC trial as the first RCT comparing laparoscopic versus open resection for colorectal cancer in 2005 provided comparable outcomes for the laparoscopic and the open approach [2]; nevertheless, conversion to open surgery was associated with a higher chance for positive CRM along with an increased risk for local recurrence. Later RCTs such as COLOR II and COREAN could not reproduce an association of conversion with positive 
Table 3. Major and minor complication and conversion rates in publications on transanal total mesorectal excision (taTME)

\begin{tabular}{|c|c|c|c|c|c|c|c|c|c|c|c|}
\hline \multirow[t]{2}{*}{ Author [ref.] } & \multirow[t]{2}{*}{ Year } & \multirow[t]{2}{*}{$\begin{array}{l}\text { Study } \\
\text { design }\end{array}$} & \multicolumn{3}{|c|}{$\begin{array}{l}\text { Major complication rate, } \\
\text { CD III-V }\end{array}$} & \multicolumn{3}{|c|}{$\begin{array}{l}\text { Minor complication rate, } \\
\text { CD I-II }\end{array}$} & \multicolumn{3}{|c|}{ Conversion rate } \\
\hline & & & laTME, \% & taTME, \% & $\mathrm{p}$ & laTME, \% & taTME, \% & $\mathrm{p}$ & laTME, \% & taTME, \% & $\mathrm{p}$ \\
\hline Dumont [61] & 2012 & CS & NR & NR & & NR & NR & & & 0 & \\
\hline Rouanet [62] & 2013 & CS & & NR & & & NR & & & 6.7 & \\
\hline Sylla [63] & 2013 & CS & & 0 & & & 60 & & & 0 & \\
\hline Lacy [64] & 2013 & CS & & 0 & & & 33.3 & & & NR & \\
\hline Velthuis [65] & 2014 & MCC & NR & NR & & NR & NR & & NR & NR & \\
\hline Atallah [66] & 2014 & CS & & NR & & & NR & & & NR & \\
\hline Chouillard [51] & 2014 & CCS & NR & NR & & NR & NR & & 26.7 & 44.4 & 0.47 \\
\hline Zoron [67] & 2014 & $\mathrm{CS}$ & & 11.1 & & & NR & & & 11.1 & \\
\hline Atallah $[68]$ & 2014 & CS & & 0 & & & 33.3 & & & 0 & \\
\hline Fernandez-Hevia [69] & 2015 & MCC & 14 & 8 & 0.17 & 38 & 25 & 0.17 & 0 & 0 & - \\
\hline D’Angelis [70] & 2015 & MCC & 15.6 & 6.2 & 0.663 & 21.9 & 18.8 & 0.663 & 3.1 & 3.1 & 1.0 \\
\hline Lacy [71] & 2015 & CS & & 10 & & & 23.6 & & & 0 & \\
\hline Tuech [72] & 2015 & CS & & NR & & & NR & & & 4.3 & \\
\hline Gomez Ruiz [73] & 2015 & $\mathrm{CS}$ & & 0 & & & 20 & & & 0 & \\
\hline Perdawood [74] & 2016 & MCC & NR & NR & & NR & NR & & 16 & 0 & 0.055 \\
\hline Chen [75] & 2016 & MCC & 4 & 2 & - & 0.13 & 0.12 & - & 5 & 2 & 0.380 \\
\hline Rasulov [76] & 2016 & CCS & 8.6 & 0 & 0.661 & 17.3 & 27 & 0.661 & 4.3 & 4.5 & 0.368 \\
\hline
\end{tabular}

Table 4. Pathological outcome in publications on transanal total mesorectal excision (taTME)

\begin{tabular}{|c|c|c|c|c|c|c|c|c|c|c|}
\hline \multirow[t]{2}{*}{ Author } & \multirow[t]{2}{*}{ Year } & \multirow{2}{*}{$\begin{array}{l}\text { Study } \\
\text { design }\end{array}$} & \multicolumn{3}{|c|}{ Completeness of TME } & \multicolumn{3}{|c|}{ Positive circumferential margin } & \multicolumn{2}{|l|}{ Harvested lymph nodes } \\
\hline & & & laTME, \% & taTME, \% & $\mathrm{p}$ & laTME, \% & taTME, \% & $\mathrm{p}$ & taTME/roTME : laTME & $\mathrm{p}$ \\
\hline Dumont [61] & 2012 & CS & & 100 & & & 0 & & $16(8-22)$ & \\
\hline Rouanet [62] & 2013 & CS & & 100 & & & 6.7 & & $3(8-32)$ & \\
\hline Sylla [63] & 2013 & CS & & 100 & & & 0 & & $33 \pm 15$ & \\
\hline Lacy [64] & 2013 & CS & & 100 & & & 0 & & NR & \\
\hline Velthuis [65] & 2014 & MCC & 72 & 96 & $<0.05$ & 8 & 4 & - & $14(7-24): 13(1-36)$ & 0.42 \\
\hline Atallah [66] & 2014 & CS & & 55 & & & 5 & & $22.5(9-51)$ & \\
\hline Chouillard [51] & 2014 & CCS & 77.8 & 53.3 & 0.41 & NR & NR & & $10.8 \pm 4.3: 12.3 \pm 9.9$ & 0.61 \\
\hline Zoron [67] & 2014 & CS & & 66.7 & & & 11.1 & & 13 & \\
\hline Atallah [68] & 2014 & CS & & 33.3 & & & 0 & & $35(18-39)$ & \\
\hline Fernandez-Hevia [69] & 2015 & MCC & 94.6 & 91.9 & 0.6 & 0 & 0 & - & $14.3 \pm 6: 14.7 \pm 6$ & 0.94 \\
\hline D’Angelis [70] & 2015 & MCC & 75 & 84.4 & 0.611 & 9.4 & 3.1 & 0.342 & $17.06: 18.63$ & 0.697 \\
\hline Lacy [71] & 2015 & CS & & 97.1 & & & 6.4 & & $14.7 \pm 6.8$ & \\
\hline Tuech [72] & 2015 & CS & & 84 & & & 5.7 & & $12(7-29)$ & \\
\hline Gomez Ruiz [73] & 2015 & CS & & 100 & & & 0 & & $14 \pm 9$ & \\
\hline Perdawood [74] & 2016 & MCC & 68 & 80 & 0.113 & 16 & 4 & 0.349 & $21(9-42): 22(7-45)$ & 0.778 \\
\hline Chen [75] & 2016 & MCC & NR & NR & $<0.05$ & NR & NR & & $16.7 \pm 7.8: 17.4 \pm 8.9$ & 0.553 \\
\hline Rasulov [76] & 2016 & CCS & 74 & 68 & 0.859 & 0 & 4.5 & 0.31 & $17(0-54): 20(8-56)$ & 0.144 \\
\hline
\end{tabular}

laTME = Laparoscopic total mesorectal excision; $\mathrm{NR}=$ not reported; $\mathrm{CS}=$ case series; CCS = comparative case series; $\mathrm{MCC}=$ matched case control trial.

CRM $[3,30]$. As the CLASICC trial represents the learning curve of LS, this might explain the differences in the findings.

However, LS continues to be challenging, especially for rectal cancer. A striking coefficient is the patient-specific individual anatomy and tumor manifestation: A narrow male pelvis, obesity, and bulky and low tumors can substantially hamper LS $[8,9,16,28]$. Hence, RS was proposed and has already demonstrated ability to address the problem of anatomical limitations in low anterior resection. 
Shorter LOS, less pain, and lower demand for analgesics result in faster convalescence after roTME. Several authors consider less tissue trauma in RS due to subtle retraction by robotic arms and fine dissection as a main reason for less pain and shorter LOS [22, 54]. Overall, this underlines the safety and feasibility of colorectal RS.

Feasibility is also reflected in a shorter learning curve: Especially in roTME, fewer cases are needed for surgeons to adapt to the robotic technique in comparison to its laparoscopic counterpart. Jimenez-Rodriguez et al. [55] suggested 21-23 cases, which is in line with the 20 cases recommended by Kim et al. [56]. Bokhari et al. [57] suggested 15-25 cases. All are less compared to 35-50 cases recommended by Wishner et al. [58] for laTME.

As evidence level 1 publications on RS for rectal malignancies are still rare, this analysis is mainly based on retrospective analyses and a non-controlled randomized trial. 2 RCTs, 1 reporting on 36 cases of right colectomy and the other on 162 cases of rectal cancer, are the only available evidence level publications. Even though this data reveals the safety and feasibility of RS, no high-evidence trials are available to support this finding. TaTME is a promising alternative to conventional laTME addressing anatomical limitations like male, narrow, obese pelves, with similar oncological outcomes and a tendency towards shorter operation times and LOS.

In conclusion, RS is a promising tool for the implementation of minimally invasive surgery in an increasing number of patients. A combination of both taTME and RS will likely become a promising strategy in selected patients [59], while prospective randomized trials are needed to prove the advantages of this approach over conventional laTME [60].

\section{Disclosure Statement}

There are no personal conflicts of interest of any of the authors.

\section{References}

1 Spaner SJ, Warnock GL: A brief history of endoscopy, laparoscopy, and laparoscopic surgery. J Laparoendosc Adv Surg Tech A 1997;7:369-373.

2 Guillou PJ, Quirke P, Thorpe H, Walker J, Jayne DG Smith AM, Heath RM, Brown JM; MRC CLASICC trial group: Short-term endpoints of conventional versus laparoscopic-assisted surgery in patients with colorectal cancer (MRC CLASICC trial): multicentre, randomised controlled trial. Lancet 2005;365:1718-1726.

3 Jeong SY, Park JW, Nam BH, et al: Open versus laparoscopic surgery for mid-rectal or low-rectal cancer after neoadjuvant chemoradiotherapy (COREAN trial): survival outcomes of an open-label, non-inferiority, randomised controlled trial. Lancet Oncol 2014;15:767-774.

4 Kang SB, Park JW, Jeong SY, et al: Open versus laparoscopic surgery for mid or low rectal cancer after neoadjuvant chemoradiotherapy (COREAN trial): shortterm outcomes of an open-label randomised controlled trial. Lancet Oncol 2010;11:637-645.

5 Jayne DG, Thorpe HC, Copeland J, Quirke P, Brown JM, Guillou PJ: Five-year follow-up of the Medical Research Council CLASICC trial of laparoscopically assisted versus open surgery for colorectal cancer. $\mathrm{Br} J$ Surg 2010;97:1638-1645.

6 Nelson H, Sargent D, Wieand HS, et al; Clinical Outcomes of Surgical Therapy Study Group: A comparison of laparoscopically assisted and open colectomy for colon cancer. N Engl J Med 2004;350:2050-2059.

7 Veldkamp R, Kuhry E, Hop WC, Jeekel J, Kazemier G, Bonjer HJ, Haglind E, Pahlman L, Cuesta MA, Msika S, Morino M, Lacy AM; COlon cancerLaparoscopic or Open Resection Study Group (COLOR): Laparoscopic surgery versus open surgery for colon cancer: shortterm outcomes of a randomised trial. Lancet Oncol 2005;6:477-484.

8 Zhou Y, Wu L, Li X, Wu X, Li B: Outcome of laparoscopic colorectal surgery in obese and nonobese patients: a meta-analysis. Surg Endosc 2012;26:783-789.

9 Akiyoshi T, Kuroyanagi H, Oya M, Konishi T, Fukuda M, Fujimoto Y, Ueno M, Miyata S, Yamaguchi T: Factors affecting the difficulty of laparoscopic total mesorectal excision with double stapling technique anastomosis for low rectal cancer. Surgery 2009; 146:483-489.

Lower Gastrointestinal Surgery: Robotic Surgery versus Laparoscopic Procedures
10 Arezzo A, Passera R, Ferri V, Gonella F, Cirocchi R, Morino M: Laparoscopic right colectomy reduces short-term mortality and morbidity. Results of a systematic review and meta-analysis. Int J Colorectal Dis 2015;30:1457-1472.

11 Jayne DG, Guillou PJ, Thorpe H, Quirke P, Copeland J, Smith AM, Heath RM, Brown JM; UK MRC CLASICC Trial Group: Randomized trial of laparoscopic-assisted resection of colorectal carcinoma: 3 -year results of the UK MRC CLASICC Trial Group. J Clin Oncol 2007; 25:3061-3068.

12 Trastulli S, Cirocchi R, Listorti C, Cavaliere D, Avenia N, Gulla N, Giustozzi G, Sciannameo F, Noya G, Boselli C: Laparoscopic vs. open resection for rectal cancer: a meta-analysis of randomized clinical trials. Colorectal Dis 2012;14:e277-296.

13 Mathis KL, Nelson H: Controversies in laparoscopy for colon and rectal cancer. Surg Oncol Clin N Am 2014; 23:35-47.

14 Huang MJ, Liang JL, Wang H, Kang L, Deng YH, Wang JP: Laparoscopic-assisted versus open surgery for rectal cancer: a meta-analysis of randomized controlled trials on oncologic adequacy of resection and long-term oncologic outcomes. Int J Colorectal Dis 2011;26:415-421.

15 Krane MK, Fichera A: Laparoscopic rectal cancer surgery: where do we stand? World J Gastroenterol 2012; 18:6747-6755.

16 Scheidbach H, Rose J, Huegel O, Yildirim C, Kockerling F: Results of laparoscopic treatment of rectal cancer: analysis of 520 patients. Tech Coloproctol 2004; 8(suppl 1):s22-24.

17 Makin GB, Breen DJ, Monson JR: The impact of new technology on surgery for colorectal cancer. World J Gastroenterol 2001;7:612-621.

18 Hance J, Rockall T, Darzi A: Robotics in colorectal surgery. Dig Surg 2004;21:339-343.

19 Rockall TA, Darzi A: Robot-assisted laparoscopic colorectal surgery. Surg Clin North Am 2003;83:1463-1468, xi.

20 Pigazzi A, Ellenhorn JD, Ballantyne GH, Paz IB: Robotic-assisted laparoscopic low anterior resection with total mesorectal excision for rectal cancer. Surg Endosc 2006;20:1521-1525.

21 Xiong B, Ma L, Zhang C: Robotic versus laparoscopic gastrectomy for gastric cancer: a meta-analysis of short outcomes. Surg Oncol 2012;21:274-280.
22 Baik SH, Ko YT, Kang CM, Lee WJ, Kim NK, Sohn SK, Chi HS, Cho CH: Robotic tumor-specific mesorectal excision of rectal cancer: short-term outcome of a pilot randomized trial. Surg Endosc 2008;22:1601-1608.

23 Bianchi PP, Ceriani C, Locatelli A, Spinoglio G, Zampino MG, Sonzogni A, Crosta C, Andreoni B: Robotic versus laparoscopic total mesorectal excision for rectal cancer: a comparative analysis of oncological safety and short-term outcomes. Surg Endosc 2010;24:28882894.

24 Park JS, Choi GS, Lim KH, Jang YS, Jun SH: S052: a comparison of robot-assisted, laparoscopic, and open surgery in the treatment of rectal cancer. Surg Endosc 2011;25:240-248.

25 DeSouza AL, Prasad LM, Ricci J, Park JJ, Marecik SJ, Zimmern A, Blumetti J, Abcarian H: A comparison of open and robotic total mesorectal excision for rectal adenocarcinoma. Dis Colon Rectum 2011;54:275-282.

26 Speicher PJ, Englum BR, Ganapathi AM, Nussbaum DP, Mantyh CR, Migaly J: Robotic low anterior resection for rectal cancer: a national perspective on shortterm oncologic outcomes. Ann Surg 2015;262:1040 1045.

27 Kang J, Yoon KJ, Min BS, Hur H, Baik SH, Kim NK, Lee KY: The impact of robotic surgery for mid and low rectal cancer: a case-matched analysis of a 3-arm comparison - open, laparoscopic, and robotic surgery. Ann Surg 2013;257:95-101.

28 Baukloh JK, Reeh M, Spinoglio G, Corratti A, Bartolini I, Mirasolo VM, Priora F, Izbicki JR, Gomez Fleitas M, Gomez Ruiz M, Perez DR: Evaluation of the robotic approach concerning pitfalls in rectal surgery. Eur J Surg Oncol 2017;43:1304-1311.

29 Liberati A, Altman DG, Tetzlaff J, Mulrow C, Gotzsche PC, Ioannidis JP, Clarke M, Devereaux PJ, Kleijnen J, Moher D: The PRISMA statement for reporting systematic reviews and meta-analyses of studies that evaluate health care interventions: explanation and elaboration. PLoS Med 2009;6:e1000100.

30 Van der Pas MH, Haglind E, Cuesta MA, Furst A, Lacy AM, Hop WC, Bonjer HJ; Colorectal cancer Laparoscopic or Open Resection II (COLOR II) Study Group: Laparoscopic versus open surgery for rectal cancer (COLOR II): short-term outcomes of a randomised, phase 3 trial. Lancet Oncol 2013;14:210-218. 
31 Baik SH, Kwon HY, Kim JS, Hur H, Sohn SK, Cho CH, Kim H: Robotic versus laparoscopic low anterior resection of rectal cancer: short-term outcome of a prospective comparative study. Ann Surg Oncol 2009;16: 1480-1487.

32 Bonjer HJ, Deijen CL, Haglind E; COLOR II Study Group: A randomized trial of laparoscopic versus open surgery for rectal cancer. N Engl J Med 2015;373:194.

33 Moloo H, Mamazza J, Poulin EC, Burpee SE, Bendavid Y, Klein L, Gregoire R, Schlachta CM: Laparoscopic resections for colorectal cancer: does conversion survival? Surg Endosc 2004;18:732-735.

34 Chan AC, Poon JT, Fan JK, Lo SH, Law WL: Impact of conversion on the long-term outcome in laparoscopic resection of colorectal cancer. Surg Endosc 2008;22: 2625-2630.

35 Slim K, Pezet D, Riff Y, Clark E, Chipponi J: High morbidity rate after converted laparoscopic colorectal surgery. Br J Surg 1995;82:1406-1408.

36 Strohlein MA, Grutzner KU, Jauch KW, Heiss MM Comparison of laparoscopic vs. open access surgery in patients with rectal cancer: a prospective analysis. Dis Colon Rectum 2008;51:385-391.

37 Pugliese R, Di Lernia S, Sansonna F, Maggioni D, Ferrari GC, Magistro C, Costanzi A, De Carli S, Artale S, Pugliese F: Laparoscopic resection for rectal adenocarcinoma. Eur J Surg Oncol 2009;35:497-503.

38 Cho MS, Baek SJ, Hur H, Min BS, Baik SH, Lee KY, Kim NK: Short and long-term outcomes of robotic versus laparoscopic total mesorectal excision for rectal cancer: a case-matched retrospective study. Medicine 2015;94:e522.

39 Kim JY, Kim NK, Lee KY, Hur H, Min BS, Kim JH: A comparative study of voiding and sexual function after total mesorectal excision with autonomic nerve preservation for rectal cancer: laparoscopic versus robotic surgery. Ann Surg Oncol 2012;19:2485-2493.

40 Nagtegaal ID, van de Velde CJ, Marijnen CA, van Krieken JH, Quirke P; Dutch Colorectal Cancer Group; Pathology Review Committee: Low rectal cancer: a call for a change of approach in abdominoperineal resection. J Clin Oncol 2005;23:9257-9264.

41 Nagtegaal ID, van de Velde CJ, van der Worp E, Kapiteijn E, Quirke P, van Krieken JH; Cooperative Clinical Investigators of the Dutch Colorectal Cancer Group: Macroscopic evaluation of rectal cancer resection specimen: clinical significance of the pathologist in quality control. J Clin Oncol 2002;20:1729-1734.

42 Hiranyakas A, da Silva G, Wexner SD, Ho YH, Allende D, Berho M: Factors influencing circumferential resection margin in rectal cancer. Colorectal Dis 2013;15 298-303.

43 Allemann P, Duvoisin C, Di Mare L, Hubner M, Demartines N, Hahnloser D: Robotic-assisted surgery improves the quality of total mesorectal excision for rectal cancer compared to laparoscopy: results of a case-controlled analysis. World J Surg 2016;40:10101016.

44 Quirke P, Dixon MF: The prediction of local recurrence in rectal adenocarcinoma by histopathological examination. Int J Colorectal Dis 1988;3:127-131.

45 Wibe A, Rendedal PR, Svensson E, Norstein J, Eide TJ, Myrvold HE, Soreide O: Prognostic significance of the circumferential resection margin following total mesorectal excision for rectal cancer. Br J Surg 2002;89: 327-334.

46 D’Annibale A, Pernazza G, Monsellato I, Pende V, Lucandri G, Mazzocchi P, Alfano G: Total mesorectal excision: a comparison of oncological and functional outcomes between robotic and laparoscopic surgery for rectal cancer. Surg Endosc 2013;27:1887-1895.
47 Collinson FJ, Jayne DG, Pigazzi A, Tsang C, Barrie JM, Edlin R, Garbett C, Guillou P, Holloway I, Howard H, Marshall H, McCabe C, Pavitt S, Quirke P, Rivers CS, Brown JM: An international, multicentre, prospective, randomised, controlled, unblinded, parallel-group trial of robotic-assisted versus standard laparoscopic surgery for the curative treatment of rectal cancer. Int J Colorectal Dis 2012;27:233-241.

48 Ma B, Gao P, Song Y, Zhang C, Zhang C, Wang L, Liu H, Wang Z: Transanal total mesorectal excision (taTME) for rectal cancer: a systematic review and meta-analysis of oncological and perioperative outcomes compared with laparoscopic total mesorectal excision. BMC Cancer 2016;16:380.

49 Deijen CL, Tsai A, Koedam TW, Veltcamp Helbach M, Sietses C, Lacy AM, Bonjer HJ, Tuynman JB: Clinical outcomes and case volume effect of transanal total mesorectal excision for rectal cancer: a systematic review. Tech Coloproctol 2016;20:811-824.

50 Koedam TW, van Ramshorst GH, Deijen CL, Elfrink AK, Meijerink WJ, Bonjer HJ, Sietses C, Tuynman JB: Transanal total mesorectal excision (taTME) for rectal cancer: effects on patient-reported quality of life and functional outcome. Tech Coloproctol 2017;21:25-33.

51 Chouillard E, Chahine E, Khoury G, Vinson-Bonnet B, Gumbs A, Azoulay D, Abdalla E: NOTES total mesorectal excision (TME) for patients with rectal neoplasia: a preliminary experience. Surg Endosc 2014;28: $3150-3157$.

52 Stevenson AR, Solomon MJ, Lumley JW, Hewett P, Clouston AD, Gebski VJ, Davies L, Wilson K, Hague W, Simes J; ALaCaRT Investigators: Effect of laparoscopic-assisted resection vs. open resection on pathological outcomes in rectal cancer: the ALaCaRT randomized clinical trial. Jama 2015;314:1356-1363.

53 Fleshman J, Branda M, Sargent DJ, et al: Effect of laparoscopic-assisted resection vs. open resection of stage II or III rectal cancer on pathologic outcomes: the ACOSOG Z6051 randomized clinical trial. Jama 2015; 314:1346-1355.

54 Patel CB, Ragupathi M, Ramos-Valadez DI, Haas EM: A three-arm (laparoscopic, hand-assisted, and robotic) matched-case analysis of intraoperative and postoperative outcomes in minimally invasive colorectal surgery. Dis Colon Rectum 2011;54:144-150.

55 Jimenez-Rodriguez RM, Diaz-Pavon JM, de la Portilla de Juan F, Prendes-Sillero E, Dussort HC, Padillo J: Learning curve for robotic-assisted laparoscopic rectal cancer surgery. Int J Colorectal Dis 2013;28:815-821.

56 Kim YW, Lee HM, Kim NK, Min BS, Lee KY: The learning curve for robot-assisted total mesorectal excision for rectal cancer. Surg Laparosc Endosc Percutan Tech 2012;22:400-405.

57 Bokhari MB, Patel CB, Ramos-Valadez DI, Ragupathi M, Haas EM: Learning curve for robotic-assisted laparoscopic colorectal surgery. Surg Endosc 2011;25:855860.

58 Wishner JD, Baker JW Jr, Hoffman GC, Hubbard GW 2nd, Gould RJ, Wohlgemuth SD, Ruffin WK, Melick CF: Laparoscopic-assisted colectomy. The learning curve. Surg Endosc 1995;9:1179-1183.

59 Atallah S: Assessment of a flexible robotic system for endoluminal applications and transanal total mesorectal excision (taTME): could this be the solution we have been searching for? Tech Coloproctol 2017;21: 809-814.

60 Deijen CL, Velthuis S, Tsai A, Mavroveli S, de Langede Klerk ES, Sietses C, Tuynman JB, Lacy AM, Hanna GB, Bonjer HJ: COLOR III: a multicentre randomised clinical trial comparing transanal TME versus laparoscopic TME for mid and low rectal cancer. Surg Endosc 2016;30:3210-3215.
61 Dumont F, Goere D, Honore C, Elias D: Transanal endoscopic total mesorectal excision combined with single-port laparoscopy. Dis Colon Rectum 2012;55:9961001.

62 Rouanet P, Mourregot A, Azar CC, Carrere S, Gutowski M, Quenet F, Saint-Aubert B, Colombo PE: Transanal endoscopic proctectomy: an innovative procedure for difficult resection of rectal tumors in men with narrow pelvis. Dis Colon Rectum 2013;56:408-415.

63 Sylla P, Bordeianou LG, Berger D, Han KS, Lauwers GY, Sahani DV, Sbeih MA, Lacy AM, Rattner DW: A pilot study of natural orifice transanal endoscopic total mesorectal excision with laparoscopic assistance for rectal cancer. Surg Endosc 2013;27:3396-3405.

64 Lacy AM, Adelsdorfer C, Delgado S, Sylla P, Rattner DW: Minilaparoscopy-assisted transrectal low anterior resection (LAR): a preliminary study. Surg Endosc 2013;27:339-346.

65 Velthuis S, Nieuwenhuis DH, Ruijter TE, Cuesta MA Bonjer HJ, Sietses C: Transanal versus traditional laparoscopic total mesorectal excision for rectal carcinoma. Surg Endosc 2014;28:3494-3499.

66 Atallah S, Martin-Perez B, Albert M, deBeche-Adams T, Nassif G, Hunter L, Larach S: Transanal minimally invasive surgery for total mesorectal excision (TAMISTME): results and experience with the first 20 patients undergoing curative-intent rectal cancer surgery at a single institution. Tech Coloproctol 2014;18:473-480.

67 Zorron R, Phillips HN, Wynn G, Neto MP, Coelho D, Vassallo RC: 'Down-to-up' transanal notes total mesorectal excision for rectal cancer: preliminary series of 9 patients. J Minim Access Surg 2014;10:144-150.

68 Atallah S, Martin-Perez B, Pinan J, Quinteros F, Schoonyoung H, Albert M, Larach S: Robotic transanal total mesorectal excision: a pilot study. Tech Coloproctol 2014;18:1047-1053.

69 Fernandez-Hevia M, Delgado S, Castells A, Tasende M, Momblan D, Diaz del Gobbo G, DeLacy B, Balust J, Lacy AM: Transanal total mesorectal excision in rectal cancer: short-term outcomes in comparison with laparoscopic surgery. Ann Surg 2015;261:221-227.

70 De'Angelis N, Portigliotti L, Azoulay D, Brunetti F; Transanal total mesorectal excision for rectal cancer: a single center experience and systematic review of the literature. Langenbecks Arch Surg 2015;400:945-959.

71 Lacy AM, Tasende MM, Delgado S, Fernandez-Hevia M, Jimenez M, De Lacy B, Castells A, Bravo R, Wexner SD, Heald RJ: Transanal total mesorectal excision for rectal cancer: outcomes after 140 patients. J Am Coll Surg 2015;221:415-423.

72 Tuech JJ, Karoui M, Lelong B, De Chaisemartin C, Bridoux V, Manceau G, Delpero JR, Hanoun L, Michot F: A step toward notes total mesorectal excision for rectal cancer: endoscopic transanal proctectomy. Ann Surg 2015;261:228-233.

73 Gomez Ruiz M, Parra IM, Palazuelos CM, Martin JA, Fernandez CC, Diego JC, Fleitas MG: Robotic-assisted laparoscopic transanal total mesorectal excision for rectal cancer: a prospective pilot study. Dis Colon Rectum 2015;58:145-153.

74 Perdawood SK, Al Khefagie GA: Transanal vs. laparoscopic total mesorectal excision for rectal cancer: Initial experience from Denmark. Colorectal Dis 2016;18: 51-58.

75 Chen CC, Lai YL, Jiang JK, Chu CH, Huang IP, Chen WS, Cheng AY, Yang SH: Transanal total mesorectal excision versus laparoscopic surgery for rectal cancer receiving neoadjuvant chemoradiation: a matched casecontrol study. Ann Surg Oncol 2016;23:1169-1176.

76 Rasulov AO, Mamedli ZZ, Gordeyev SS, Kozlov NA, Dzhumabaev HE: Short-term outcomes after transanal and laparoscopic total mesorectal excision for rectal cancer. Tech Coloproctol 2016;20:227-234. 